COMUNICAÇÃO BREVE

CADERNOS DE

NATUROLOGIA

qunusur

\title{
THERMAL MEDICINE IN POLAND
}

\section{MEDICINA TERMAL NA POLÔNIA}

\begin{abstract}
In developed countries the profile of health care is changing. Its aim is not only the longevity but also quality of life. Maintaining physical and mental activity and lack of pain are equally important factors. Thermal therapy seems to be good answer to this challenge. Thermal treatment in Poland has had a long tradition for many centuries and it is an integral part of national health care system. It is approved by most medical authorities. The treatment is reimbursed by national insurance system and on average lasts 3 weeks. The basis treatment contains natural products procedures. Additionally, kinezytherapy, hydrotherapy and physical medicine procedures are used. In 44 thermal stations, which operate 12 months a year, mainly chronic diseases are treated. Moreover, rehabilitation is provided especially in case of orthopaedic-traumatic and rheumatologic diseases. Curing properties of applied methods are confirmed in scientific research. The treatment is supervised by doctors, specialists in balneology field. The procedures are applied by physiotherapists and other professional health care workers. Whole thermal therapy system is supervised by Minister of Health via State Consultant and regional consultants. In the current demographic situation it seems obvious that thermal therapy with its favourable ratio of health advantages to costs has evident chances not only for maintaining its vital role in Polish national health care system but also for further development.
\end{abstract}

\section{KEYWORD}

Crenobalneotherapy.

Poland.

Thermalism.

Public Health.

CORRESPON DENTE

Jacek Chojnowski

Nicolaus Copernicus University Ludwik Rydygier Collegium

Medicum in Bydgoszcz

ul. Leśna 3 - 87-720 Ciechocinek

E - M A I L

jacchojnowski@gmail.com

Recebido: 07/06/2014

Aprovado: 12/09/2014 


\section{RESUMO}

Nos países desenvolvidos, o perfil dos cuidados à saúde está mudando. Seu objetivo não é só a longevidade, mas também a qualidade de vida. A manutenção da atividade física e mental e a ausência de dor são fatores igualmente importantes. A terapia termal parece ser uma boa respostaa esse desafio. $O$ tratamento termal na Polônia tem uma longa tradição de muitos séculos e é parte integrante do sistema nacional de saúde. É aprovado pela maioria das autoridades médicas. $\mathrm{O}$ tratamento é reembolsado pelo sistema nacional de seguros e, em média, dura três semanas. $O$ tratamento básico contém procedimentos com produtos naturais. Além disso, procedimentos de fisioterapia, hidroterapia e medicina física são usados. Em 44 estações térmicas, que operam os 12 meses do ano, doenças crônicas são tratadas principalmente. Além disso, a reabilitação é fornecida especialmente no caso de doenças ortopédicas e reumatológicas. As propriedades de cura dos métodos aplicados são confirmados em pesquisa científica. $O$ tratamento é supervisionado por médicos especialistas no campo da balneologia. Os procedimentos são aplicados por fisioterapeutas e outros profissionais de saúde. Todo o sistema de terapia termal é supervisionado pelo Ministério da Saúde através do Consultor Estadual e de consultores regionais. Na atual situação demográfica, parece óbvio que a terapia termal, com sua relação favorável de vantagens para a saúde e custos, tem chances evidentes não só para a manutenção de seu papel vital no sistema nacional de cuidados de saúde polonês, como também para um maior desenvolvimento.

PALAVRAS-CHAVE: Balneoterapia. Polônia. Termalismo. Saúde Pública.

Thermal medicine in Poland has been practised for centuries. The first notes about this kind of treatment appeared in the $11^{\text {th }}$ century. Polish chronicles inform that Polish princess Judyta, who was king Władysław Herman’s wife, used mineral water springs in the area of contemporary health resort Busko-Zdrój in the center of Poland. In the following centuries Polish kings and aristocracy were treated in thermal stations, which is confirmed by numerous notes.

The first currently known essay about hydrotherapy was written by Marcin of Miechów in 1522 . However, the first book about mineral water written in Polish was titled Cieplice and it was published in Krakow in 1578 by Wojciech Oczko. The author described Polish thermal stations working at that time, types of mineral water and indications to treatment. That is why he is called the creator of Polish balneology.The greatest period for Polish thermal treatment was $18^{\text {th }}$ and $19^{\text {th }}$ centuries. At that time thermal treatment used to be to the most important branch of medicine in Europe. Physicians did not know other effective methods of curing many diseases.

After the Second World War Prof. J. Jankowiak made special contributions to Polish balneology. He founded Balneoclimatological Institute in Poznań, was the editor of many balneological books and teacher and master for several generations of Polish balneologists.

Polish Balneological Association has existed since 1905, but its contemporary name is Polish Association of Balneology and Physical Medicine. However, the first balneological branch of Polish Physician Society was created in 1870.Polish Association of Balneology and Physical Medicine has been publishing its own journal Acta Balneologica, every two years it organises congresses featuring national and foreign experts in the field. It has over 600 members - physicians who are specilists in balneology. It also takes a dynamic part in forming standards and guidelines. Moreover, it inspires research in the field of balneology.

The development of modern balneology was stopped in the second part of the $20^{\text {th }}$ century. Medical achievements enabled to use drugs and methods which are far more effective than balneological procedures. Many countries rejected this type of treatment due to lack scientific evidence. Thermal treatment was abolished in some European countries, the USA and Canada. In addition to 
this, many countries resigned from reimbursement of thermal therapy.

Current experience shows, however, that modern medicine cannot answer to all patients's health problems. Firstly, pharmacology often induces negative side effects. Secondly, patients after surgical operations usually need follow-up treatment and rehabilitation. Thirdly, quality of life, reduction of pain and independence of sick and elderly people are equally important as the life expectancy. Therefore, balneological treatment is an effective answer to these problems.

Poland is a country rich in natural resources which are used for thermal treatment. All over the country there are various deposits of mineral water, peloids (borowina) and natural gases $\left(\mathrm{CO}_{2}, \mathrm{H} 2 \mathrm{~S}, \mathrm{Ra}, \mathrm{O}_{3}\right)$.

Therapeutic waters are certified in Poland by Ministry of Health. To get the certificate such water must be underground, free from bacteriological and chemical pollution, and has stable content. Its therapeutic effect must be proved in scientific research ornoticed in long-term clinical observations. If such water contains more than $1000 \mathrm{mg}$ of mineral ingredients, it is called mineral therapeutic water.

The richest in therapeutic mineral water is the Carpathian mountains region where you can find bicarbonate water and chloride sodium water.In Busko-Zdrój and Solec area there are sulphide hydrogen water

The next region rich intherapeutic mineral water is the Sudety mountains where apart fromhydrocarbonate water also radon waters in Świeradów-Zdrój and Czerniawa-Zdrój occur. Moreover, thermal fluoride waters exist in Cieplice-Zdrój. In lowlands the common mineral waters are natrium-chloride waters which frequently contain bromide and jodide.

Therapeutic mineral water are mainly applied for bathing. Other forms of therapy are drinking therapy and inhalations.

The main peloid occuring in Poland is peat (in Polish it is called borowina). Borowina is organic peloid which was created in natural environment and has curing effect. The process leading to creating borowina was action of microorganisms in an- aerobic conditions and with excess of water. In Poland there are two types of borowina deposits:

- high type with high level of organic content (more than 95\%), low level of mineral content and acid $\mathrm{pH}$

- low type with high level of mineral content, low level of organic content (80-90\%) and neutral or slightly alcalic $\mathrm{pH}$. The whole area of borowina deposits covers 3500 ha located all over the country. Their own borowina deposits are used in 14 thermal stations. The most famous of them are Kołobrzeg, Połczyn-Zdrój, Kamień Pomorski, Wieniec-Zdrój and Krynica. The main organic ingredients of peat are: humic acids, waxes, resins and carbohydrates, proteins, alcaloids, enzymes, pectins. Mineral ingredients of peat are: macro- and micro-ingredients. The macro-ingredients are: chloride, sulphur, carbohydrates, calcium, magnesium, potassium. natrium and ferrum. Micro-ingredients are: manganese,cobalt, zinc, bromine, iodine, fluorine, copper. Therapeutic effectiveness of peat depends both on thermal and chemical conditions. Low thermal conductivity and relatively high heat capacity allow to apply peat in overheating treatment. On the other hand, unique chemical properties of peat are the base of extrathermal properties: antiinflamatory, bacteriostatic, bactericidal, overheating, regenerating and endocrine. Unprocessed peat is used in the form of thick poultice because of thermal conditions. Ground in a ball mill, homogeneous peat (peat paste) is applied in the form of thin poultice in body temperature. In this case chemical properties are used. Peat is applied in the form of whole body poultice, partial poultice, bathing of whole body or only limbs and tampons.

Natural therapeutic gas used in treatment is carbodioxide. It is located mainly in the Carpathian mountains. All-body bathing in carbodioxide has mainly vasodilatation effects and first of all is used for circulatory diseases treatment. In most Polish thermal stations, however, artificial carbodioxide is used. Other gases used in thermal therapy in Poland are: radon (located mainly in Świeradów-Zdrój and Czerniawa-Zdrój), artificially obtained oxygen and ozone and nitrogen applied in cryotherapy. 
Thermal medicine in Poland is an integral part of health care system. The first legal act concerning thermal treatment was the Act of Parliament from 1922. It regulated what areas can be recognized as thermal and it specified criteria and requirements which must be met by thermal station. Current legal fundaments for operating of thermal stations are regulated by Act of Parliament passed in 2005. There are also more than 100 subsidiary legislation acts announced by Minister of Health in the field of thermal medicine. According to this act, thermal treatment is realisedat thermal stations area, in thermal treatment departments and it is based on natural therapeutic products, healing climate and microclimate conditions. Additionally, the physical treatment is used.The cost of treatment is fully covered by national insurance (National Health Fund) in thermal hospitals. In thermal sanatorium the patient only covers a part of accommodation and meals costs. The time of treatment lasts on average 3 weeks, only in some cases it is extended to 4 weeks. A specialist in balneology and physical medicine orders all therapeutic procedures and is also responsible for the whole treatment. These procedures are performed by qualified physiotherapists. The place where thermal procedures take place is thermal treatment departments It is supervised by balneologists and physiotherapists. The procedures may be used by patients treated in thermal hospitals, thermal sanatoriums and out-patient thermal clinics. In a thermal hospital a patient is given day care by doctors and nurses. In thermal sanatorium they are given day care by nurses only, besides they are ensured an everyday contact with a leading doctor. The sanatorium treatment is aimed at patients with less serious health problems. The reimbursement of thermal treatment costs is possible every two years. Moreover, thermal stations offer fully-paid curing service for both national and foreign visitors. Both in reimbursement and commercial treatment it is ordered and supervisedby a balneologist.

The main direction of thermal stations activity is therapy of patients suffering from chronic diseases. In Poland you can find 18 different treatment profiles including all key groups of chronic diseases which positively react to thermal therapy. Every thermal station according to its therapeutic resources, climate features and employed professional staff conducts from one to several treatment profiles. Treatment profiles of thermal stations are confirmed by Minister of Health when they accomplish required conditions.Most thermal stations offer therapy in orthopaedic-traumatic and rheumatologic profile. Among other popular profiles are cardiologic, metabolic, pulmonary diseases and otolaryngologic. Apart from treatment, thermal stations realize preventive and rehabilitation programs. They have also diagnostic possibilities which - first of all - enable to monitor thetherapycorrectly. Vital elements of therapy in a thermal station are also educational programs aimed at changing lifestyle habits for healthier ones. Healthpromoting education is a vital element of holistic treatment in a thermal station. In case of chronic diseases, the success of treatment depends largely on the sick person's lifestyle. The aim of health education is to change the lifestyle into a a healthier one and to perfect the ability to cope with problems induced by a chronic disease. Illness prevention and health promotion programs are also connected with health education realised in a thermal station.

Only those thermal department which implement educational and preventive programs can apply for reimbursement of treatment costs by national insurance system.

In Poland there are 45 thermal stations. $70 \%$ of them are situated in the highland areas. It is the result of thermal springs localisation. The others are located in lowland andseasidearea. The best known are: Wieliczka located in a salt mine, Krynica-Zdrój rich in specific mineral waters, Busko-Zdrój with its sulphur water, Ciechocinek with the oldest in the world brine graduation towers (tężnie), a seaside resort and thermal station Kołobrzeg with its own peat mine. At the seaside (not further than $3 \mathrm{~km}$ from the coast)there are 6 thermal stations. 16 thermal stations are located on lowlands lower than $200 \mathrm{~m}$ above sea level. 14 thermal stations are situated between $200 \mathrm{~m}$ and $400 \mathrm{~m}$ above sea level. 8 thermal stations can be find in uplands, between $400 \mathrm{~m}$ and $800 \mathrm{~m}$ above sea level.The map of Polish Thermal Station is presented in Figure 1. 
Figure 1: Polish thermal stations

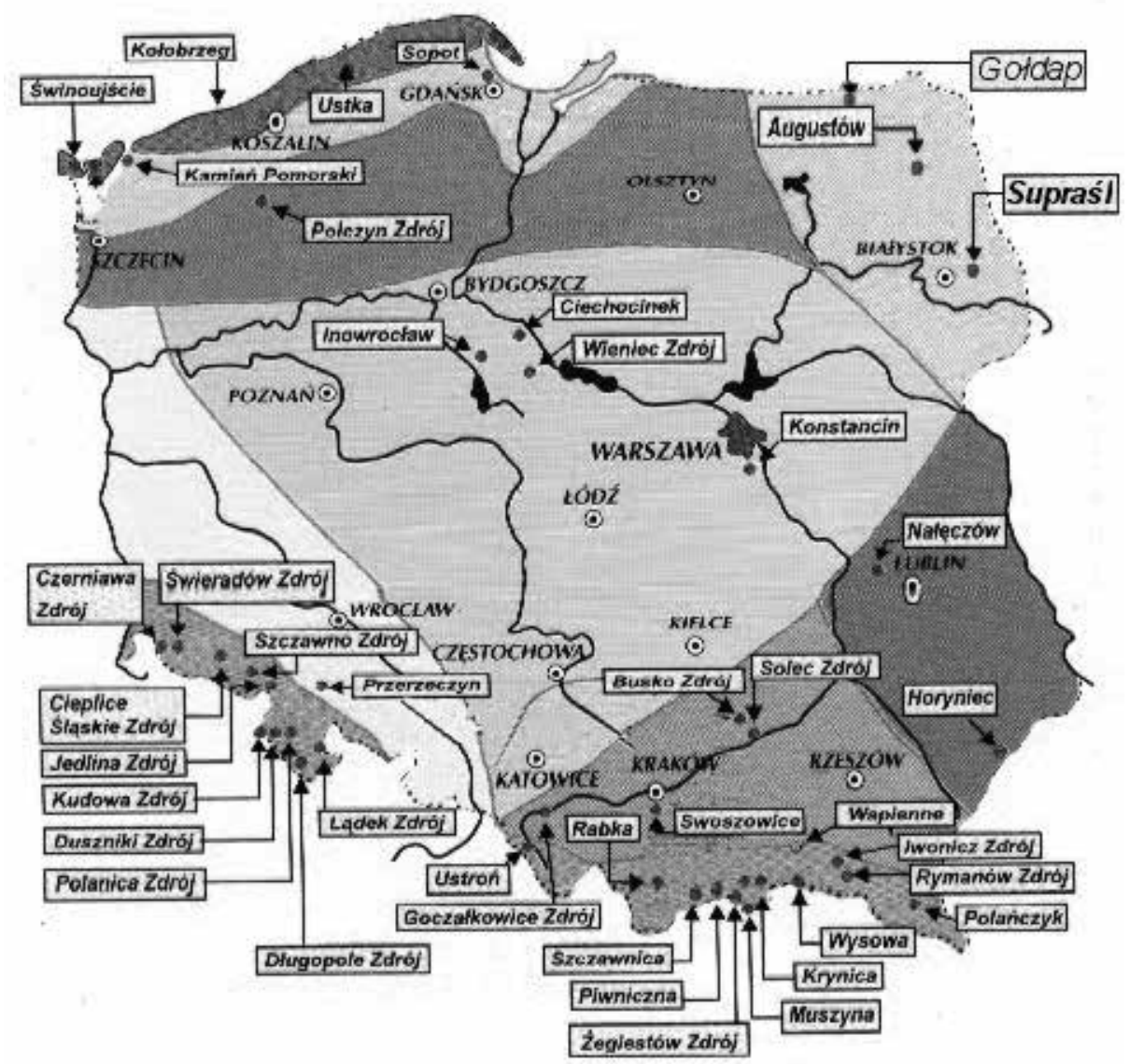

Polish thermal stations offer 37,800 beds in about 240 thermal treatment departments. 1,900 beds are prepared for children and youths under 18. On average thermal treatment departments administrate 160 beds, the smallest have 44 beds, the biggest nearly 400. Among them 65 arethermal hospitals with 25\% of all beds.

Thermal therapy is provided in Polish thermal stations all year round. On average a bed in thermal hospital is used more than 300 days a year. However, commercial patients prefer summer period for their treatment. Statistically, 1 in 75 Polish citizen is treated in thermal treatment departments. In 2010 thermal treatment departments treated 638,000 inpatients and outpatients, $60 \%$ of them were females while about $4 \%$ were children and youths under 18 . The number of patients treated in thermal treatment departments has been increasing for the last few years. The tendency concerns also foreign patients. On average 40,000 of them are treated in Poland, the most popular resort among foreign patients is Kołobrzeg.
On the whole 30 million procedures are applied in thermal treatment departments a year. Natural resources procedures make one third of them. Among natural resources procedures $30 \%$ are mineral baths, $35 \%$ are peat procedures. Apart of natural resources procedures of kinezytherapy (22\%), hydrotherapy (12\%) and physical medicine procedures (20\%) are performed.

Balneological and physical medicine training for doctors is realised mainly as postgraduate education. Specialisation in Balneology and Physical Medicine lasts two years. Only a specialist in another field of medicine can apply for this subject of studies. The training includes, apart from clinical knowledge, information about bioclimatology, mineral resources geology, mineral waters chemistry. During the specialisation period a physician should work in thermal treatment department and do practice in thermal clinics. Specialisation ends in state examination. About 30 doctors a year graduate from the specialisation.

In Poland scientific institutions conduct research in the field of thermal medicine. About 15 research 
centers have their results published both in national and international journals. In Poland since 1945 more than 4000 papers have been published in balneology field. Natural mineral products used in thermal treatment have been thoroughly examined. Many articles confirm curing activity of Polish natu-

\section{FONTE DE FINANCIAMENTO}

\author{
Nenhuma
}

\section{CONFLITO DE INTERESSES}

Declara não haver

\section{REFERENCES}

1. Chojnowski J, Ponikowska I, Szmurło W. Badania Kliniczne nad wykorzystaniem kąpieli ozonowych w leczeniu niedokrwienia kończyn dolnych. Balneologia Polska 1998;40-52

2. Drobnik M. Biologiczne oddziaływanie kwasów huminowychi fulwonowych zawartych w preparatach borowinowych. Funkcja stężenia czy postaci? Balneologia Polska 1995; 3-7

3. Jakóbik K. et all. Lecznictwo uzdrowiskowe w Polsce w latach 2002010. Główny Urząd Statystyczny 2012

4. Kucharski M. Złoża borowiny udokumentowane w kategorii “B” I uznane za lecznicze. Balneologia Polska 1995; 1-90

5. Latour T, Czajka K. Fizyczne I chemiczne badania porównawcze przydatności do celów leczniczych borowin typu niskiego i wysokiego. Balneologia Polska 1994 3-4; 107-110

6. Ponikowska I. Odległe wyniki leczenia chorych ze zmianami zwyrodnieniowymi stawów w warunkach uzdrowiskowych. Balneologia Polska 1994; 36-57

7. Ponikowska I. Kompedium balneologii. Rekomendacje Krajowego Konsultanta. Wydawnictwo A. Marszałek, Toruń 2001 ral mineral products. Obviously, for methodological and financial reasons the number of double-blind randomised trials is restricted. However, papers presenting results of single-blind randomised trials are more and more often published as they also have good scientific value.
8. Ponikowska I. Propozycja zmian nazewnictwa i definiowania najważniejszych terminów używanych w balneologii i medycynie fizykalnej. Balneologia Polska 2007; 49-54

9. Ponikowska I. Adamczyk P. Vu K. The clinical principles of balneology and physical medicine. Massage Therapy Journal 2003;41,4: 88-103

10. Ponikowska I. Chojnowski J. Kwiatkowska B. Szafkowski R Cukrzyca - standardy lecznicze i profilaktyczne w medycynie uzdrowiskowej. Balneologia Polska 2004; 46, 1-2: 11-24

11. Samborski W.Ponikowska I. Choroby reumatyczne - standardy lecznicze w medycynie uzdrowiskowej

12. Włodarczyk K. Ponikowska I. Chojnowski J. Oczachowska S Enzymatyczny układ antyoksydacyjny $\mathrm{u}$ chorych $\mathrm{z}$ niedokrwieniem kończyn dolnych na tle miażdżycy makroangiopatii cukrzycowej poddanych balneoterapii. Balneologia Polska 2002; 44-52 